\title{
FROM INCULCATING ISLAMIC VALUES TO 'RAHMATAN-LIL-ALAMIN': PROMULGATING VARIOUS APPROACHES OF ISLAM IN MALAYSIA
}

\author{
Abdul Mua'ti Zamri bin Ahmad \\ Faculty of Modern Languages and Communication \\ Universiti Putra Malaysia 43400 UPM Serdang, Selangor \\ Email:abmuati@upm.edu.my
}

\begin{abstract}
The government of Malaysia has introduced 'Inculcating Islamic Values' during the reign of Prime Minister Dr Mahathir in the 80s, 'Civilizational Islam (Islam Hadhari)' during the reign of Prime Minister Abdullah Badawi in 2004, 'Wasatiyah' during the reign of Prime Minister Najib Razak in 2010 and 'Rahmatan-lil-Alamin' recently in 2018 under the new government. All the approaches were designed towards developing a modern society in predominantly Malay-Muslim society of Malaysia. The concepts were normally publicized as a part of the manifesto during the political campaigns prior to the general elections. Since then, Malaysians, Muslims and non-Muslims alike were expecting to observe more detail explanations of the concepts and how it could be translated into actions in the multi-religion society. Occasionally the Prime Minister will reiterate the approaches and spell out in detail the methods of implementing the concept or to translate the concepts into policies. The concepts will further be elaborated in a couple more speeches delivered by the Prime Minister and senior ministers including the information minister. The mainstream media has also allotted special columns and programs to outspread the concepts even though at times not in detail and lack of continuity. Today, after about one year since the latest concept (Rahmatanlil-alamin) has been conceived, what are the peoples' perceptions towards it? Do the people really made to understand the concept? To what extent has the media been used to disseminate the idea? This paper will discuss the analysis of the dissemination of the concept through the main stream media in Malaysia.
\end{abstract}

Keywords: Islamic Values, Rahmatan-Lil-Alamin, Promulgating, Approaches of Islam

\section{Introduction}

Since the formation of Malaysia, the federal government has always been interested to expand and strengthen its program on Islamic affairs. This is in line with the constitution that stipulates that Islam is the religion of the federation. In this regard, during the reign of the fourth prime minister, several new efforts have been taken, including the establishment of religious centers, the International Islamic University, Islamic Banking System, Islamic Insurance Company and the strengthening of the Islamic Affairs Division of the Prime Minister's Department. Consistent with this effort, another initiative called 'The Implementation of Islamic Values in Administration' was introduced in 1985. 
In order to succeed in the administration of the Government, the government believes that values of Islam can be practiced by all Malaysians, whether they are Muslims or non-Muslims. According to the Prime Minister, the most important values to be inculcated in the administration by the Muslims and non-Muslims alike are honesty, responsibility, diligence, sincerity, organized, discipline, prioritizing the community over oneself, being willing to sacrifice, not greedy, forward looking, good moral, behave well and so on.

The basic objectives of the initiatives are as follows:

(i) to establish a distinguished, discernable Malaysian society respected by other communities;

(ii) to establish a 'blissful state';

(iii) to eliminate negative attitudes in carrying out duties and responsibilities, and

(iv) to produce high quality services.

Based on these objectives it is clear that this policy is not intended to convert the non-Muslims of Malaysia, but rather to promote the practice of values that are acceptable to all parties and groups because other religions also emphasize the practice of such values. Only eleven of the many Islamic values have been selected to form the basis of this policy. The values are trustworthy, responsible, sincere, dedicated, moderate, diligent, clean, discipline, cooperative, virtuous, and grateful.

Subsequently the concept of Islam Hadhari was first introduced by the fifth Prime Minister of Malaysia, Dato' Seri Abdullah Haji Ahmad Badawi. It was first delivered in his speech at the United Malays National Organization (UMNO)'s $55^{\text {th }}$ General Assembly in Kuala Lumpur, Malaysia, on September 23, 2004 (Abdullah Ahmad Badawi, 2006). Overall, it was an approach that aimed on achieving a balanced state of life in both physical and spiritual arenas - intended to evoke the Malaysian mind, especially the Malay Muslims, to enhance their spiritual and material strength in a holistic form via the acquisition of knowledge. The actual aim of this new governance (the premier began his office in 2003) is non-other than founding a knowledge-based society in the future. In accordance with Islam Hadhari, the reigning party (UMNO) is held responsible for ensuring Muslims to meet current challenges without deviating from their faith, while the door of ijtihad (independent reasoning based on the reference texts) will remain open so that interpretations are suited to the developmental needs of the prevailing time and conditions. Furthermore, all policies must be balanced, and broad-based development plans should encompasses the infrastructure and the economy, human resource development through a comprehensive education program, the inculcation of noble values through spiritual development and the assimilation of Islamic values. In short, Islam Hadhari was aimed at achieving 10 main principles:

1. Faith and piety in Allah;

2. A just and trustworthy government;

3. A free and independent people;

4. A vigorous pursuit and mastery of knowledge;

5. A balanced and comprehensive economic development; 
6. A good quality of life for the people;

7. Protection of the rights of minority groups and women;

8. Cultural and moral integrity;

9. Safeguarding the natural resources and the environment; and

10. Strong defense capabilities.

Nevertheless from that moment onward, Islam Hadhari has become the latest campaign of the government. This campaign, however, is not entirely new to us. In truth, Islamization and the Islamic concept of development had been with us long before we gained our independence. There had been numerous approaches by the government in promoting Islam before (Terence Chong, 2005). Every time, it came in a new package to tally with the contemporary needs and requirements of that period. Besides, never had been two governments in the world are alike in approach or practice - though they might have grown from the same seed and nourished from the same root.

The establishment of Institute of Islam Hadhari in 2007 at Universiti Kebangsaan Malaysia with Sheikh Abdullah Fahim Chair is a commitment of the Government of Malaysia and the university to:

(a) develop research activities in Islamic civilization, and

(b) integrate the idea of inculcating Islamic values proposed by Tun Dr. Mahathir Mohamad, the fourth Prime Minister of Malaysia, in the agenda of nation building.

The idea of Islam Hadhari associates with the fifth Prime Minister of Malaysia, Tun Abdullah Ahmad Badawi, is to further strengthening the Vision 2020 introduced by Dr. Mahathir Mohamad. Additionally, the sixth Prime Minister of Malaysia, Dato' Seri Najib Tun Abdul Razak, introduced the concept of Wasatiyah in his opening speech at the Convention of Wasatiyah as a mean to establish 1Malaysia concept. The Wasatiyah approach emphasizes on objective and subjective knowledge that will produce a just, moderate, and balance human beings in all aspect of societal life, i.e., between worldly and hereafter needs, ideal and reality, acquired and revealed knowledges. Moderation as perceived by the western society is not similar to the concept of Wasatiyah, as in the concept of Wasatiyah, God is considered as a focal and prime point in nation building while the concept of moderation emphasizes on the right of individual over the right of society as a whole.

Following the fall of the National Front in the $14^{\text {th }}$ general election in May 2018, the new government introduces a new concept called Rahmatan lil Alamin (Mercy to all creations). This new concept is expected to be adopted as a policy soon. Minister in the Prime Minister's Department Datuk Seri Mujahid Yusof Rawa said the working paper on the concept is now in its final draft before it is presented to the Cabinet by late of September or latest, by early October. He said the scholars will present, debate and provide input into the concept based on four issues comprising 'Syumul' (universal), 'Mutakamil' (comprehensive) and 'Ilmiah' (knowledge), 'Adab alikhtilaf (ethics of disagreement) in overcoming extremism as well as on today's realities and hope. Rahmatan lil Alamin has been approved by the Rulers' Council and 
had also been approved via a meeting of the Islamic National Council for Islamic Religious Affairs Malaysia, which was chaired by Prime Minister Tun Dr Mahathir Mohamad on March 14, 2019. The concept is based on the 'Maqasid Syariah' (goals and objectives of Syariah) and the Malaysian Model, which was introduced last year. On expanding the understanding of the concept, Mujahid hoped that by next year, it would be introduced into the civil service and the proposed policy would be used by those who are relevant not merely confined to those in academic field.

\section{Civilized Islam as the Stem of Islamic Approaches in Malaysia}

Malaysia began as a middle-income country where a large percentage of the people were very poor when we gained independence on August 31, 1957. But because we opted for democracy, those wanting to win elections were forced to care for poor in order to gain their support. Because of this, we provided the poor especially in the rural areas with needed infrastructure, health care, education facilities, and skills training. Today, they are no longer as poor. Today, they enjoy all the amenities of the richer urban areas. Since Malaysia gained her independence, we have opted for democracy. This Federation of Malay States was established on February 1948 as result of a treaty between the Malay monarchs and the King George VI of Britain. This new structure was actually an alternative plan of governance replacing the much-rejected 'Malayan Union' proposed by the British rulers (Mohd. Salleh Abas, 1987).

This newly set-up government of Malaysia at that time was practically too fragile, with no experience neither of governing nor of comprehending the actual meaning of democracy at all. In fact, majority of newly independent nations that emerged after the World War II suffered the same problem. We have no one to turn up, or to refer to. The so-declared independent nations that emerged were totally artificial. The inhabitants of different races and tribes had got along with each other during the colonial period not by their choices. The colonial masters imposed from above a semblance of unity. The only form of government that we had back then were authoritarian colonial rule which complete with detention without actual trial and banishment to remote parts of the world. Nevertheless, these authoritarian colonial powers and their metropolitan governments insisted that we, the newly independent country to adopt a democratic forms of government with which they had no experience. Nevertheless, the racial composition of Malaysia is the key to understanding the whole picture. It dictates the pattern of the economy, helped to shape the constitution, and influenced the democratic process and the party system (Means, 1991).

The Malaysian school system may have imparted some common values and beliefs about Malaysian political and social institutions, but ideological and behavioral indoctrination was not considered to be a responsibility to the schools or any other agency of government. The Prime Minister then, Tunku Abdul Rahman seemed to follow the strategy of listening closely but acting carefully. This urgency was very much delayed and only after the May 13, 1969 riot, the reshaping of the public opinion and political culture became a major concern of government policy. Thus, the Rukunegara or 'National Ideology' (i.e. the 5 national goals: Belief in God, Loyalty to King, Upholding the Constitution, Rule of Law, Good Behavior and Morality) came into existence. This Rukunegara was vigorously propagated as embodying the 
country's original social compact that was considered as the minimum basic to sustain social order and provide a firmer government. Since then, all imported television programs were carefully chosen, and local productions were extensively produced. All of these measures were taken to ensure that all of the screening contents would be consonant to the national goals set out in Rukunegara (Hock, 1991).

Since Islam is stipulated in the Constitution as the religion of the Federation of Malaya (later Malaysia), Islam has been the fundamental of all laws and regulations practiced in the country. Nonetheless, taking into consideration the composition of the multiracial and multi religious Malaysians, Islam that underlies the 'way of life' of Malaysians must be the one accepted by everyone. Therefore, Islam in Malaysia must be seen as a modern, progressive and civilized belief.

Literally, hadhari means "the civilized". It was originated from Arabic words -al-Islam al-Hadhari. In short, Islam Hadhari meant a concept of Islamic practice that stressed upon a civilizational development. In simpler phrases, they may also be substituted for "Civilizational Islam" - the very word used by Abdullah Ahmad Badawi himself in trying to explain Islam Hadhari (Abdullah Ahmad Badawi, 2006). However, the comprehensive definition of Islam Hadhari is "civilization and refinement in social culture in accordance with the Islamic perspectives of civilization". This approach is perceived as a more comprehensive notion rather than approaching Islamic practices in a secular form (i.e. tackling the Islamic principles and practices separately).

Since its introduction to the Malaysian public, Islam Hadhari has been misunderstood as a new mazhab (denomination), if not to the extreme a new religion among the non-Muslims. This misunderstanding mostly is due to the inaccurate way the people choose to perceive the actions of the government. When Abdullah Ahmad Badawi first introduced Islam Hadhari, he had already made it crystal clear of the notion as (Abdullah Ahmad Badawi, 2006):

" Islam Hadhari is not a new religion. It is not a new teaching nor is it a new mazhab. It is an effort to bring the ummah (worldwide community comprising all adherents of the Muslim faith) back to the basics of Islam, back to the fundamentals as prescribed in the Qur'an and the hadith, which form the foundations for an Islamic Civilization. If Islam Hadhari is interpreted sincerely and understood clearly, it will not cause Muslims to deviate from the true path."

Nevertheless, it is in fact, one of the many approaches that had been brought forth by numerous Muslim leaders in their efforts of rebuilding the Islamic glory. They came with many words and phrases - as well as visions and missions. As for Malaysian experience, the post-independence progress was marked with numerous efforts - Vision Islam (early 1990s by the then Prime Minister Mahathir Mohamad), and Islam Madani (at the end of 1990's by the then former Deputy Prime Minister Anwar Ibrahim). As for Islam Hadhari, the vision is aimed at making Malaysia a model for an Islamic state by the year 2020. In moving towards realizing the vision, Malaysian government is determined to implement all of her national developments 
and social agendas upon the universal, progressive, civilized, tolerance, and balanced Islamic approaches.

\section{Politicizing Islamic Approaches}

Islam Hadhari automatically became a campaign issue when it was delivered on September 23, 2004 - and definitely a key campaign issue during the 2004 Malaysia's general elections. Its message of a 'progressive' Islam was popular with the electorate, resulting in a ringing endorsement of Prime Minister Abdullah Ahmad Badawi at the polls on 21 March (Terence Chong, 2006). This idea of 'progressive' Islam is nothing new to the contemporary Malaysian public. In fact, it has been a recurring feature of Malaysian political landscape before the independence (under the influence of Jamaluddin Al-Afghani, Sheikh Mohd. Abduh, so on and so forth). Up to this date, the message of a 'progressive' Islam has been emphasized and deemphasized according to the prevailing political conditions. All of these demonstrated that the 'progressive' spirit of Islam Hadhari is definitely not new but a variant of political Islamic discourse in Malaysia. However, it is argued that global political shifts since September 11, 2001 have somehow created an important role for Islam Hadhari as a political discourse.

While the details of Islam Hadhari, Wasatiyah and later Rahmatan-lil-alamin concepts remain vague, it is traced to the teachings of Islamic philosopher Ibn Khaldun (1332-1406). Its notion of 'progressiveness' (mentioned in his infamous book Mukaddimah) is drawn from the adaptive mindset and practices whereby 'nomadic societies moved in a law-like manner from their tribal and primitive origins to a progressive civilization' (Dewan Bahasa, 1993). In fact, Ibn Khaldun had also described in lengthy about the importance of progressiveness as important as the religion itself. To him, it became among the fundamentals of madinah fadhlilah or supreme governance. This supreme governance is the nucleus of umran or civilization. This emphasis on social restraint and order, as well as the legitimization of the use of force, privileges state interest, and is in contrast to the more humanist and individual-centered philosophy of the Muhammad Iqbal-inspired Islam Madani (Terence Chong, 2005).

\section{Research Methodology}

In brief this quantitative study involved 500 respondents residing in the Federal Territory of Kuala Lumpur and Putrajaya. The respondents were selected by employing purposive sampling method. Data were gathered by using a set of questionnaire in July and August 2019. The demographic information of the respondents is as depicted in Table 1: 
Table 1: Respondents Demographic Characteristics $(n=500)$

\section{Age group}

$18-27$

191

38.2

28-37

150

30.0

$38-47$

97

19.4

$48-57$

52

10.4

58-67

10

2.0

\section{Gender}

Male

Female

\section{Ethnicity}

Malay

Chinese

India

Others

\section{Religion}

Islam

Buddha

Hindu

Christian

\section{Educational Attainment}

Primary School

Secondary School

Others

\section{Employment}

Government

Private

Self employed

Student

Table 1 showed that majority of the respondents involved in this study were male, age between 18-27 years old, Malay and Muslim. Most of them were either secondary school leavers or attained tertiary education from colleges or universities and serving in the private sector. 
PROMULGATING VARIOUS APPROACHES OF ISLAM IN MALAYSIA

Abdul Mua'ti @ Zamri bin Ahmad, Ph.D

\section{Findings and Discussions}

\section{Understanding of the Concept}

The study found that majority of the respondents regarded themselves as fairly understand of the concept of civilizational Islam practiced in Malaysia (Please refer Table 2).

Table 2: Respondents' Understanding of Civilizational Islam Concept $(n=500)$ Understanding Frequency Percentage (\%)

$\begin{array}{llr}\text { Really understand } & 21 & 4.2 \\ \text { Understand } & 139 & 27.8 \\ \text { Fairly understand } & \mathbf{2 2 6} & \mathbf{4 5 . 2} \\ \text { Do not understand } & 79 & 15.8 \\ \text { Do not understand at all } & 35 & 7.0\end{array}$

Moreover, in terms of ethnic groups, even the Malay respondents confirmed that they only moderately understand the concept. The Chinese and Indian respondents as predicted stated that they do not understand the concept (Table 3)

Table 3: Ethnic Group and Perception of Understanding of Civilizational Islam Concept $(n=495)$

Ethnicity

Level of understanding (\%)

\begin{tabular}{llllll} 
& 1 & 2 & 3 & 4 & 5 \\
\hline Malay & 4.9 & 32.0 & $\mathbf{5 0 . 4}$ & 11.1 & 1.6 \\
Chinese & 0.0 & 0.0 & 10.3 & $\mathbf{4 8 . 7}$ & 41.0 \\
Indian & 0.0 & 3.7 & 11.1 & $\mathbf{4 4 . 4}$ & 40.7 \\
Others & 0.0 & 25.0 & 25.0 & 25.0 & 25.0 \\
\hline 1 = Really Understand & 2 = Understand & 3 = Fairly Understand \\
4 = Do Not Understand & 5 = Do Not Understand At All
\end{tabular}

However since Malays are Muslims constitutionally in Malaysia, as can be seen in Table 4, they showed the same result as in Table 3. Obviously, the Muslims indicated that they understand the concept more than the other followers. But even that, they considered their level of understanding as only moderate.

Table 4: Religious Group and Perception of Understanding of Civilizational Islam Concept $(n=498)$

Level of Understanding (\%)

\begin{tabular}{|c|c|c|c|c|c|}
\hline \multirow{2}{*}{ Religion } & \multirow[b]{2}{*}{1} & \multirow[b]{2}{*}{2} & \multirow[b]{2}{*}{3} & \multirow[b]{2}{*}{4} & \multirow[b]{2}{*}{5} \\
\hline & & & & & \\
\hline Islam & 4.8 & 31.8 & 50.8 & 11.0 & 1.6 \\
\hline Buddha & 0.0 & 0.0 & 9.7 & 48.4 & 41.9 \\
\hline Hindu & 0.0 & 0.0 & 0.0 & 50.0 & 50.0 \\
\hline
\end{tabular}


$1=$ Really Understand

$2=$ Understand

$3=$ Fairly Understand

$4=$ Do Not Understand

$5=$ Do Not Understand At All

\section{Early Introduction of the Concept}

This study found that a great majority of the respondents stated that they came across the concept of Civilizational Islam for the first time only during the reign of Abdullah Badawi. This means these respondents only get acquainted with the concept about almost a year after it was first introduced in the wake of 2004 general election campaigns (Please refer Table 5).

Table 5: Respondents' Acquaintance With Civilizational Islam Concept $(n=500)$

\begin{tabular}{lcc}
\hline Early information & Frequency & Percentage (\%) \\
\hline Before 2004 General Election & 55 & 11.0 \\
After 2004 General Election & 133 & 26.6 \\
Recently (in 2005) & 309 & $\mathbf{6 1 . 8}$ \\
\hline
\end{tabular}

Additionally, the study also found that most respondents of all races stated that they first heard of the concept in 2005 (Table 6).

Table 6: Ethnic Group and First Heard of Civilizational Islam Concept ( $\mathrm{n}=492)$

First Heard $(\%)$

Ethnicity

\begin{tabular}{llll}
\cline { 2 - 4 } Malay & 1 & 2 & 3 \\
\hline Chinese & 12.9 & 30.4 & $\mathbf{5 6 . 7}$ \\
Indian & 0.0 & 2.7 & $\mathbf{9 7 . 3}$ \\
Others & 0.0 & 11.1 & $\mathbf{8 8 . 9}$ \\
\hline
\end{tabular}

1 = Before 2004 General Election $\quad 2$ = After 2004 General Election $3=$

Recently (in 2005)

\section{Views Towards the Concept}

Nonetheless, more respondents said that they were interested in the concept. Only a small fraction of the respondents regarded the concept as politicians' political gimmick to sway voters especially during the election times (Table 7).

Table 7: Respondents' Views Towards Civilizational Islam Concept $(n=500)$

\begin{tabular}{lcr}
\hline Views towards the concept & Frequency & Percentage (\%) \\
\hline Interested & 223 & 44.6 \\
Not interested & 126 & 25.2 \\
No views & 42 & 8.4 \\
Political gimmick & 96 & 19.2 \\
Others & 10 & 2.0 \\
\hline
\end{tabular}


The study further discovered that respondents from all age groups found the new concept interesting. Only a small number of those in the 58-67 brackets considered the introduction of the concept as political gimmick in trying to win the election. (Please refer Table 8).

Table 8: Age Group and Views Towards Civilizational Islam Concept $(\mathrm{n}=497)$

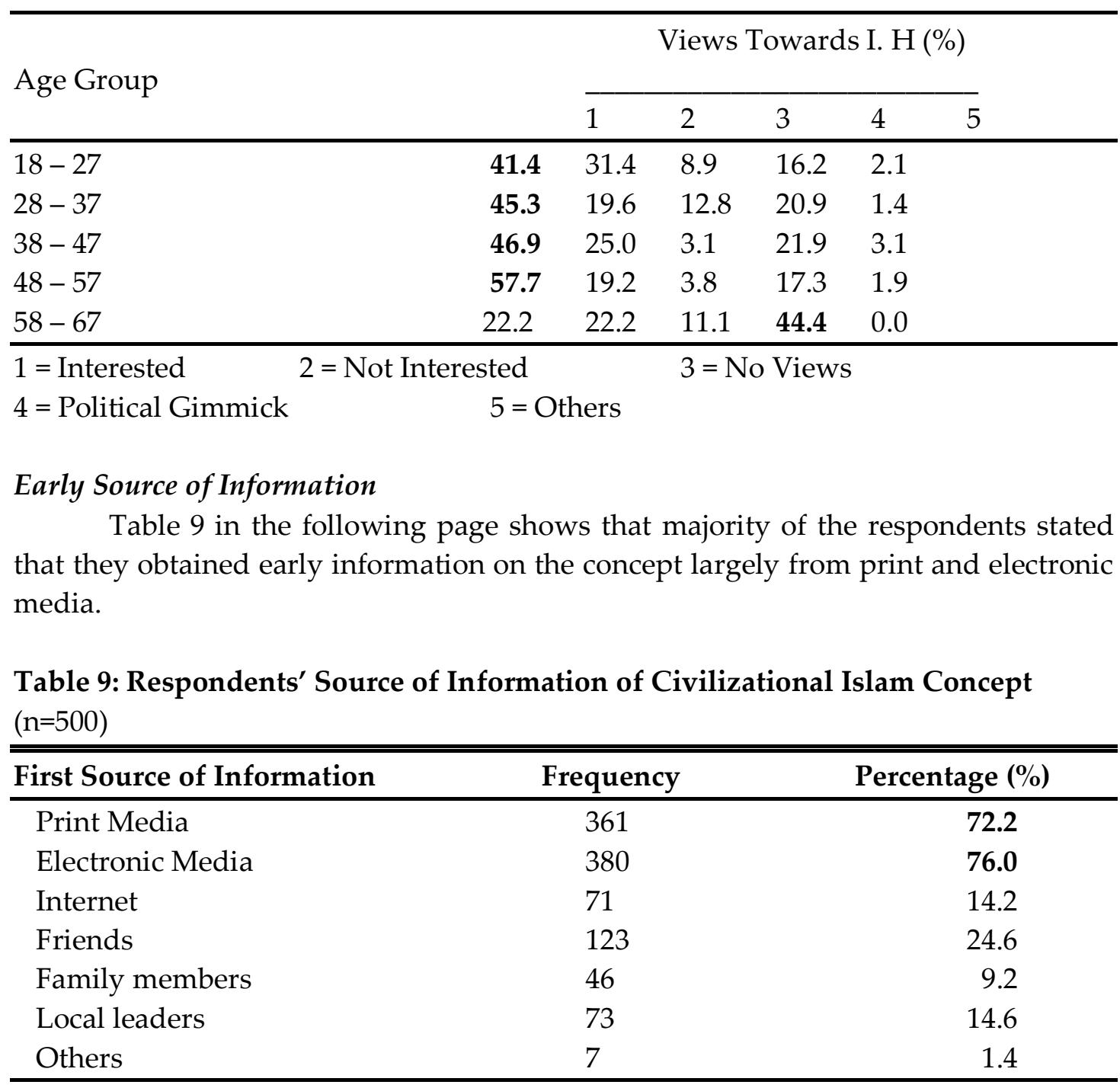

More to the point, Table 10 below shows that respondents from almost all age group obtained early information on the concept from the electronic and the print media. These were made possible since the electronic and the print media were fully utilized by the government to disseminate information regarding their new policies to the people. At any rate, the respondents from 58-67 group stated that they obtained the information mostly from the electronic media and less from the print one. This most likely because the people of this age are pensioners and spent more time in front of television sets rather than exposing themselves to reading materials. 
Table 10: Respondents' Age Group and First Source of Information on

Civilizational Islam Concept $(\mathrm{n}=500)$

C.I. a New Sect (\%)

$\begin{array}{llllll}1 & 2 & 3 & 4 & 5 & 6\end{array}$

Age group

\begin{tabular}{llllll}
$18-2764.9$ & $\mathbf{7 1 . 2}$ & 14.7 & 27.7 & 11.5 & 8.4 \\
$28-3775.3$ & $\mathbf{8 0 . 0}$ & 13.3 & 22.7 & 8.7 & 14.0 \\
$38-47 \mathbf{8 1 . 4}$ & 74.2 & 17.5 & 25.8 & 7.2 & 17.5 \\
$48-5778.8$ & $\mathbf{8 4 . 6}$ & 9.6 & 19.2 & 5.8 & 26.9 \\
$58-6744.4$ & $\mathbf{8 8 . 9}$ & 11.1 & 0.0 & 0.0 & $\mathbf{4 4 . 4}$ \\
\hline
\end{tabular}

$1=$ Print Media $\quad 2=$ Electronic Media

$3=$ Friends

$4=$ Family members $5=$ Local Leaders

$6=$ Others

Subsequently, Table 11 shows that the Malay respondents acquired information about the new concept for the first time from both print and electronic media. However, the Chinese respondents came across the concept for the first time from the electronic media. The Indian respondents are just like their fellow Malay countrymen, obtained early information on the concept from both print and electronic media.

Table 11: Ethnic Group and First Sources of Information on Civilizational Islam Concept $(n=495) \quad$ C.I. a New Sect $\quad(\%)$

\begin{tabular}{llllllll}
\hline Ethnicity & 1 & 2 & 3 & 4 & 5 & 6 & \\
\hline Malay & 75.5 & 78.4 & 15.5 & 34.0 & 10.8 & 16.5 & \\
Chinese & 46.2 & $\mathbf{6 4 . 1}$ & 10.3 & 30.8 & 0.0 & 2.6 & \\
Indian & $\mathbf{6 6 . 7}$ & 63.0 & 5.5 & 22.2 & 0.0 & 3.7 & \\
Others & 25.0 & 25.0 & 0.8 & 25.0 & 0.0 & 0.0 & $4=$ Friends \\
\hline 1 = Print media & 2 = Electronic media & & $3=$ Internet & \\
5 = Family members & 6 = Local leaders \\
\multicolumn{5}{l}{ Sources of Additional Info }
\end{tabular}

Definitely the new concept has sparked interest amongst the people. As a result, the people were driven to look for further information after getting acquainted with the new concept. The question is however, where did they go when they need more in-depth information? This study found that majority of the respondents stated that they chose print and electronic media as their sources of reference. Less people look for internet to get such information. This may be because normally new concepts conceived in the country could not easily be found in the new media. It will take sometimes until the authorities post them on the net. 
PROMULGATING VARIOUS APPROACHES OF ISLAM IN MALAYSIA

Abdul Mua'ti@ Zamri bin Ahmad, Ph.D

Table 12: Respondents' Source of References of Civilizational Islam Concept $(\mathrm{n}=500)$

\begin{tabular}{lcc}
\hline \hline Further source of information & Frequency & Percentage (\%) \\
\hline Print Media & 354 & $\mathbf{7 0 . 8}$ \\
Electronic Media & 356 & 71.2 \\
Internet & 103 & 20.6 \\
Friends & 117 & 23.4 \\
Family members & 32 & 6.4 \\
Local leaders & 62 & 12.4 \\
Others & 15 & 3.0 \\
\hline
\end{tabular}

Likewise, Table 13 below shows that both media i.e. print and electronic were chosen as favorites when the respondents from all age groups need further references on the concept. The only remarkable difference is with the 58-67 age brackets. Even though they heard about the concept for the first time from the electronic media, they also consulted print media whenever they needed additional information $(66.7 \%)$.

Table 13: Respondents' Age Group and Source of References on Civilizational Islam Concept $\quad(\mathrm{n}=500)$

\begin{tabular}{llllll} 
& \multicolumn{4}{c}{ C.I. a New Sect } & $(\%)$ \\
\hline 1 & 2 & 3 & 4 & 5 & 6
\end{tabular}

Age group

\begin{tabular}{llllll}
\hline $18-2759.7$ & $\mathbf{6 3 . 9}$ & 25.1 & 21.5 & 7.3 & 6.8 \\
$28-3774.0$ & 72.0 & 13.3 & 22.7 & 7.3 & 12.7 \\
$38-4784.5$ & 76.3 & 27.8 & 23.7 & 4.1 & 16.5 \\
$48-5778.8$ & $\mathbf{8 6 . 5}$ & 11.5 & 32.7 & 3.8 & 21.2 \\
$58-6766.7$ & $\mathbf{7 7 . 8}$ & 11.1 & 11.1 & 0.0 & 33.3
\end{tabular}

$1=$ Print Media $2=$ Electronic Media

$3=$ Friends

$4=$ Family members $\quad 5=$ Local Leaders $\quad 6=$ Others

Table 14 furthermore showed that the respondents from all ethnic groups consulted both print and electronic media for further information on the concept. This implied that both media were considered important in propagating the newly conceived concept. 
Table 14: Ethnic Group and Source of Reference on Civilizational Islam Concept $(\mathrm{n}=495)$

$$
\text { C.I. a New Sect } \quad(\%)
$$

\begin{tabular}{llllllll}
\hline Ethnicity & 1 & 2 & 3 & 4 & 5 & 6 & \\
\hline Malay & 72.9 & $\mathbf{7 4 . 1}$ & 21.4 & 23.3 & 85.9 & 14.1 & \\
Chinese & $\mathbf{5 1 . 3}$ & $\mathbf{5 1 . 3}$ & 17.9 & 25.6 & 7.9 & 2.6 & \\
Indian & $\mathbf{6 3 . 0}$ & 59.3 & 11.1 & 14.8 & 5.5 & 0.0 & \\
Others & $\mathbf{5 0 . 0}$ & 25.0 & 0.0 & 25.0 & 0.8 & 0.0 & \\
\hline 1 = Print media & 2 = Electronic media & & $3=$ Internet & 4 = Friends \\
5 = Family members & 6= Local leaders & & &
\end{tabular}

\section{Perceptions towards Civilizational Islam Concept}

The respondents were also asked of their opinion of the new concept, specifically whether they regard the concept as a new sect of the religion. Table 15 shows that respondents of all age group disagree with the notion. Only those in the 58-67 brackets considered the concept as such.

Table 15: Age Group and Perception that Civilizational Islam Concept a New Sect $(\mathrm{n}=475)$

$$
\text { C.I. a New Sect (\%) }
$$

Age Group

\begin{tabular}{llllll}
\cline { 3 - 5 } & & 1 & 2 & 3 & 4 \\
\hline $18-27$ & 34.3 & $\mathbf{4 4 . 2}$ & 17.1 & 4.4 & \\
$28-37$ & 23.0 & $\mathbf{4 4 . 6}$ & 22.3 & 10.1 & \\
$38-47$ & 19.1 & $\mathbf{5 1 . 1}$ & 24.5 & 5.3 & \\
$48-57$ & 23.5 & $\mathbf{5 6 . 9}$ & 13.7 & 5.9 & \\
$58-67$ & 11.1 & 33.3 & $\mathbf{5 5 . 6}$ & 0.0 & \\
\hline $1=$ Strongly Disagree & 2 = Disagree & \multicolumn{5}{c}{ 3= Agree } & 4 = Strongly Agree
\end{tabular}

By ethnic groups, the study revealed that most of the respondents of all races disagreed with the notion that Civilizational Islam is a new sect. However more Chinese respondents compared to other races regarded the concept as a new sect (Table 16).

Table 16: Ethnic Group and Perception that Civilizational Islam is a New Sect $(\mathrm{n}=470)$

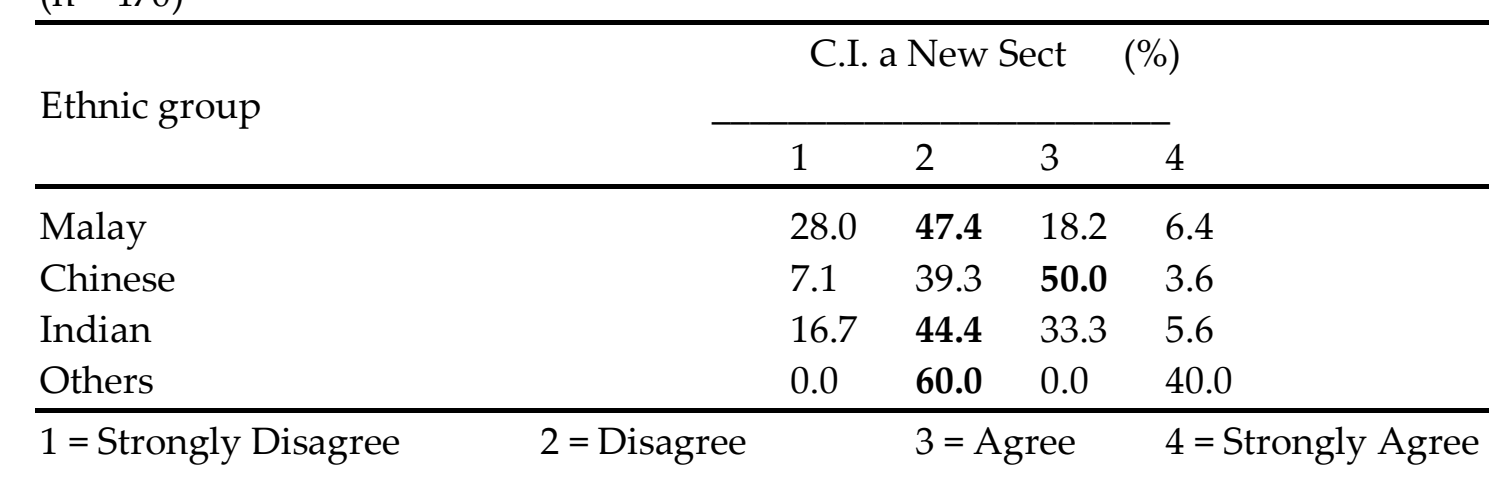


On the other hand, the study found that majority respondents of all age groups agreed that Civilizational Islam is a new approach. This understanding is parallel with the government's belief that Civilizational Islam is just a new approach in bringing modernization into the society (Table 17).

Table17: Age Group and Perception that Civilizational Islam a New Approach $(\mathrm{n}=482)$

\begin{tabular}{llllll}
\hline & & \multicolumn{5}{c}{ C.I. a New Approach (\%) } \\
\cline { 3 - 6 } Age group & & 1 & 2 & 3 & 4 \\
\hline $18-27$ & 6.6 & 24.6 & $\mathbf{5 6 . 8}$ & 12.0 & \\
$28-37$ & 2.8 & 22.5 & $\mathbf{6 0 . 6}$ & 14.1 & \\
$38-47$ & 8.4 & 20.0 & $\mathbf{5 8 . 9}$ & 12.6 & \\
$48-57$ & 13.5 & 23.1 & $\mathbf{5 3 . 8}$ & 9.6 & \\
$58-67$ & 0.0. & 44.4 & $\mathbf{5 5 . 6}$ & 0.0 & \\
& & & & & \\
\hline $1=$ Strongly Disagree & 2 = Disagree & & $3=$ Agree & 4 = Strongly Agree
\end{tabular}

More to the point, the study found that majority of respondents of all ethnic groups agrees that Islam Hadhari is just a new approach, as echoed by the government (Table 18).

Table 18: Ethnic Group and Perception that Civilizational Islam is a New Approach

$(\mathrm{n}=477)$

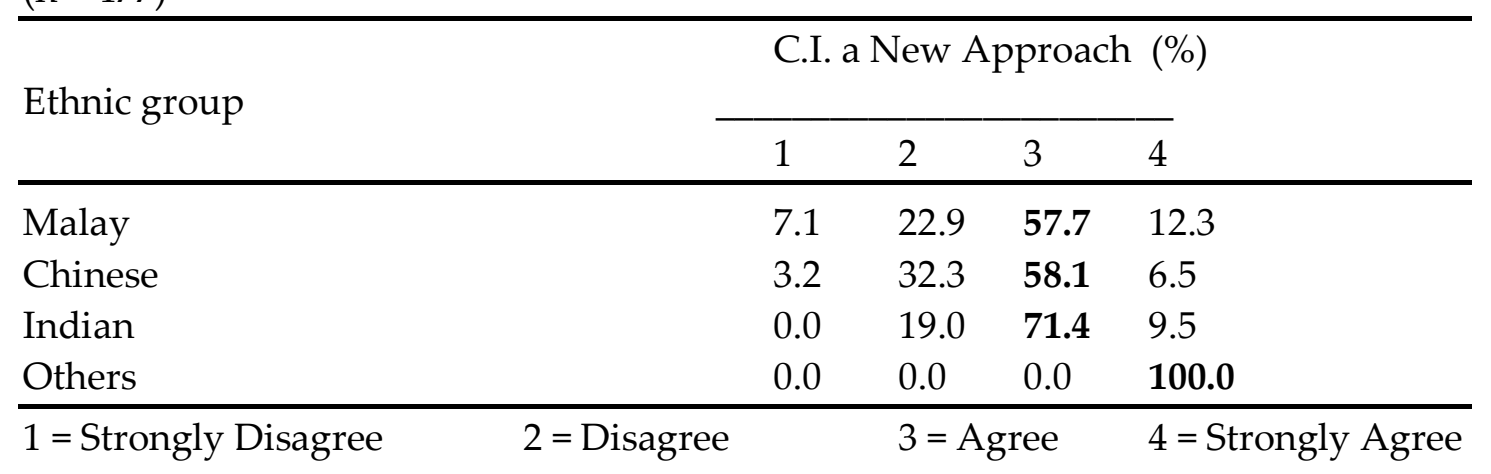

The respondents were also asked of their perception on the capability of Civilizational Islam approaches in developing all Malaysians regardless of their religion. Apparently, the study found that majority of respondents of all age groups agreed with the promising capability. Only those in the 58-67 age brackets were somewhat skeptical with the notion. (Please refer Table 19). 
Table 19: Age Group and Perception that Civilizational Islam Capable of Developing All Malaysians

$(\mathrm{n}=489)$

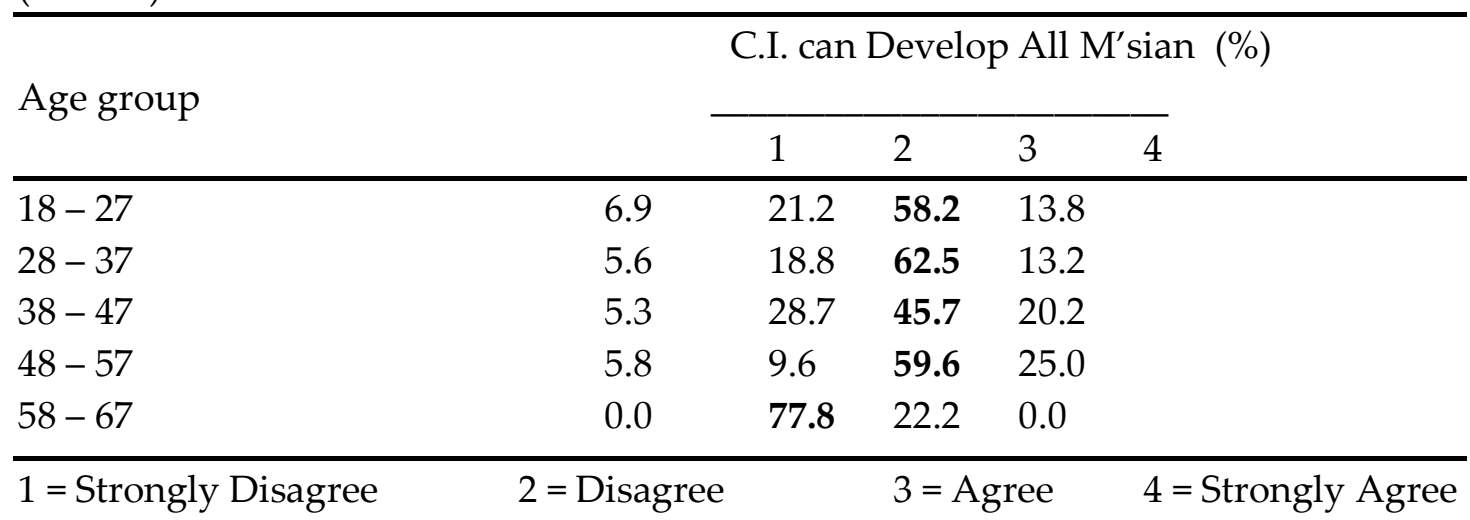

Additionally, by ethnic group, the study revealed that majority of the Malay respondents felt that Civilizational Islam could unite Malaysians of all walk of lives. However, only a slim majority of Indian respondents were of the same opinion. In contrast, more Chinese respondents disagree with this idea (Table 20).

Table 20: Ethnic Group and Perception that Civilizational Islam is Capable of Uniting Malaysians $(n=475)$

$$
\text { C.I. can Unite People (\%) }
$$

Ethnic group

\begin{tabular}{lllll} 
& 1 & 2 & 3 & 4 \\
\hline Malay & 1.9 & 19.3 & 59.8 & 19.0 \\
Chinese & 20.0 & 46.7 & 33.3 & 0.0 \\
Indian & 26.1 & 30.4 & $\mathbf{3 9 . 1}$ & 4.3 \\
Others & 0.0 & 0.0 & 0.0 & $\mathbf{1 0 0 . 0}$ \\
\hline 1 = Strongly Disagree & 2 = Disagree & \multicolumn{4}{c}{ 3= Agree } & $4=$ Strongly Agree
\end{tabular}

The study also included question on the respondents' perception towards the focus of Civilizational Islam. According to the government, Civilizational Islam will bring together both material and spiritual aspects of human development. When asked this question, majority of respondents from all age group perceived that the concept focuses on both developments (Table 21).

Table 21: Age Group and Perception that Civilizational Islam Concept Focuses on Material and Human Development

$(\mathrm{n}=471)$

C.I. Focus on Both Dev. (\%)

\begin{tabular}{llllll} 
Age group & & & & \\
\cline { 3 - 6 } & & 1 & 2 & 3 & 4 \\
\hline $18-27$ & 7.1 & 28.0 & $\mathbf{5 6 . 0}$ & 8.8 & \\
$28-37$ & 3.6 & 19.7 & $\mathbf{5 9 . 9}$ & 16.8 & \\
$38-47$ & 6.7 & 27.8 & $\mathbf{5 3 . 3}$ & 12.2 &
\end{tabular}




\begin{tabular}{lccccc}
$48-57$ & 1.9 & 25.0 & $\mathbf{6 5 . 4}$ & 7.7 & \\
$58-67$ & 0.0 & 33.3 & 55.6 & 11.1 & \\
\hline $1=$ Strongly Disagree & 2 = Disagree & & 3 = Agree & 4 = Strongly Agree
\end{tabular}

Next, the respondents were asked of their views of the capabilities of Civilizational Islam in transforming Malaysians into modern citizen. Table 22 shows that most of the respondents of all age group agreed that the concept will be able to transform the people to live a modern lives.

Table 22: Age Group and Perception that Civilizational Islam is Capable of Transforming Malaysians into Modern Citizen

$(\mathrm{n}=484)$

C.I. could Transform Malaysians (\%)

Age group

\begin{tabular}{|c|c|c|c|c|c|}
\hline & & & & & \\
\hline & & 1 & 2 & 3 & 4 \\
\hline $18-27$ & 4.8 & 25.7 & 57.8 & 11.8 & \\
\hline $28-37$ & 2.1 & 17.0 & 58.2 & 22.7 & \\
\hline $38-47$ & 2.1 & 24.5 & 52.1 & 21.3 & \\
\hline $48-57$ & 0.0 & 21.2 & 65.4 & 13.5 & \\
\hline $58-67$ & 0.0 & 22.2 & 55.6 & 22.2 & \\
\hline
\end{tabular}

$1=$ Strongly Disagree

$2=$ Disagree

$3=$ Agree

$4=$ Strongly Agree

Even though the leaders of the government reiterated that Civilizational Islam is a new approach in an effort to build a civilized nation, certain quarters in the country claimed that it is not new. Thus the respondents were asked of their perception whether the government's move is merely rebranding of the previous policy (Inculcation of Islamic Values Policy during Mahathir's era to Islam Hadhari in Abdullah's era to Wasatiyah in Najibs era and now Rahmatan-lil-alamin). Table 23 shows that majority of the respondents from all age groups agreed that the new concept is in fact a new terminology of the previous policy. This may be because the respondents could not see the significant differences between the previous policies and the latest concept.

Table 23: Age Group and Perception that the New Concept is Merely a Rebranding of the Previous Policies $(n=468)$

C.I. is a Rebranding of Old Policies (\%)

Age group

$\begin{array}{llll}1 & 2 & 3 & 4\end{array}$

\begin{tabular}{llllll}
\hline $18-27$ & 7.9 & 21.9 & $\mathbf{6 2 . 4}$ & 7.9 & \\
$28-37$ & 0.7 & 22.6 & $\mathbf{6 5 . 7}$ & 10.9 & \\
$38-47$ & 1.1 & 22.8 & $\mathbf{6 2 . 0}$ & 14.1 & \\
$48-57$ & 3.9 & 21.6 & $\mathbf{6 6 . 7}$ & 7.8 & \\
$58-67$ & 0.0 & 22.2 & 33.3 & $\mathbf{4 4 . 4}$ & \\
\hline $1=$ Strongly Disagree & 2 = Disagree & \multicolumn{5}{c}{ 3= Agree } & \multicolumn{4}{c}{ 4 = Strongly Agree }
\end{tabular}


Nonetheless, the respondents were asked whether the government should proceed with the implementation of the new concept in steering the development of Malaysia. The Malay and Indian respondents stated that they agreed the government should go ahead with the implementation. In contrast, more of the Chinese respondents disagree with the move (Table 24).

Table 24: Ethnic Group and Perception that the New Concept should be Continued $(\mathrm{n}=480)$

C.I. should be Continued (\%)

Ethnic group

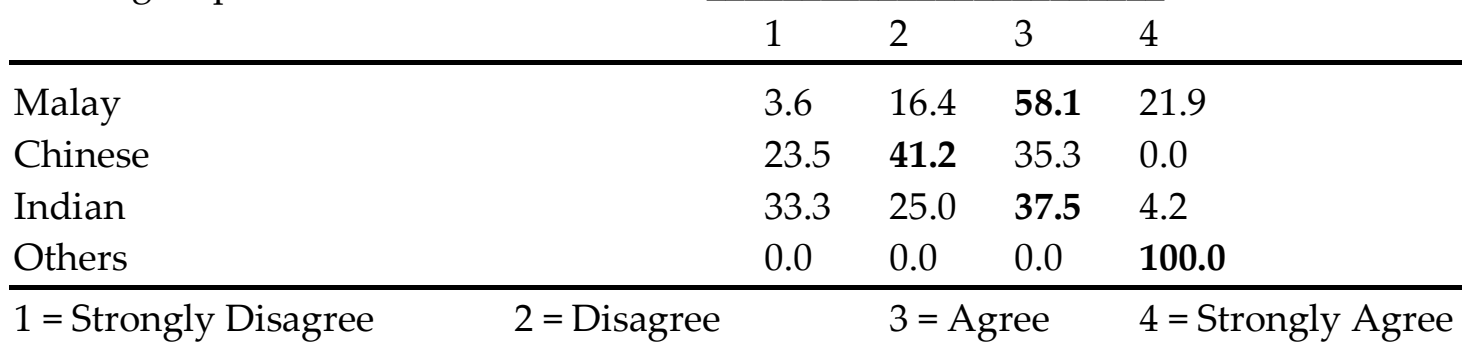

Can Civilizational Islam change the world views towards Islam? Islam has been associated with backwardness, third world, under developed, and of late with terrorism and blood shed. This study also included a question whether Civilizational Islam is capable of changing these stigmas. Apparently, a great majority of respondents regardless of their ethnic groups agreed that Civilizational Islam has the ability of doing so (Please refer Table 25). This shows the high expectations the people have towards the approach.

Table 25: Ethnic Group and Perception that Civilizational Islam will Change World's Views Towards Islam $(n=478)$

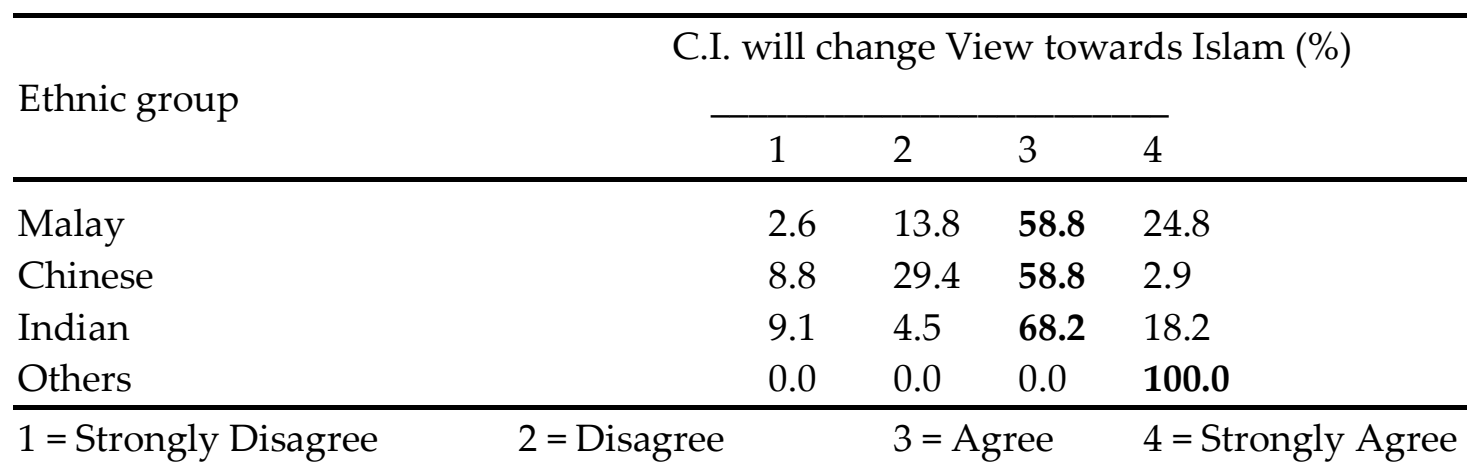

Subsequently, majority of the Malay and Indian respondents and from other ethnic groups agree with the idea that the authorities should put more information on the new concept in the newspapers. This will ensure the people of sufficient information on the new approach. This is also an indication that the people are aware of the new concept and want to know more about it. Only the Chinese respondents seemed to disagree with this proposal. 
PROMULGATING VARIOUS APPROACHES OF ISLAM IN MALAYSIA

Abdul Mua'ti @ Zamri bin Ahmad, Ph.D

\section{Proposal to the government}

Table 26: Ethnic Group and Suggestion to Put More Information through

Newspapers $(n=484)$

More C.I. Info. in Newspapers (\%)

Ethnic group

\begin{tabular}{llll}
\hline 1 & 2 & 3 & 4
\end{tabular}

\begin{tabular}{lllll}
\hline Malay & 4.0 & 23.8 & $\mathbf{5 6 . 7}$ & 15.5 \\
Chinese & 5.7 & $\mathbf{5 1 . 4}$ & 40.0 & 2.9 \\
Indian & 11.5 & 30.8 & $\mathbf{5 0 . 0}$ & 7.7 \\
Others & 33.3 & 0.0 & 0.0 & $\mathbf{6 6 . 7}$ \\
\hline 1 = Strongly Disagree & 2 = Disagree & & \multicolumn{3}{c}{ 3 = Agree } & 4 = Strongly Agree
\end{tabular}

However, Table 27 shows that most of the respondents regardless of their ethnicity agreed that the authority should use television as a channel to educate the people of the new concept. This indicates that respondents prefer television more than newspapers to be the medium in propagating the new idea.

Table 27: Ethnic Group and Suggestion to Put More Civilizational Islam Information through Television

$(\mathrm{n}=484)$

\begin{tabular}{lllll}
\hline \multirow{2}{*}{ Ethnic group } & \multicolumn{4}{c}{ More C.I. Info. in TV (\%) } \\
\cline { 2 - 5 } & 1 & 2 & 3 & 4 \\
\hline Malay & 3.8 & 19.5 & $\mathbf{6 1 . 4}$ & 15.2 \\
Chinese & 8.6 & 34.3 & $\mathbf{5 4 . 3}$ & 2.9 \\
Indian & 7.7 & 26.9 & $\mathbf{5 7 . 7}$ & 7.7 \\
Others & 33.3 & 0.0 & 0.0 & $\mathbf{6 6 . 7}$ \\
\hline 1 $=$ Strongly Disagree & 2 = Disagree & & 3 - Agree & 4 = Strongly Agree
\end{tabular}

At any rate the study also found that the internet was not a chosen medium to carry such messages. Table 28 shows that a very small majority of the Malay respondents agree that the government should use the internet to propagate Civilizational Islam, whereas most of the Chinese and Indian respondents disagreed.

Table 28: Ethnic Group and Suggestion to Put More Civilizational Islam Information through Internet $(n=482)$

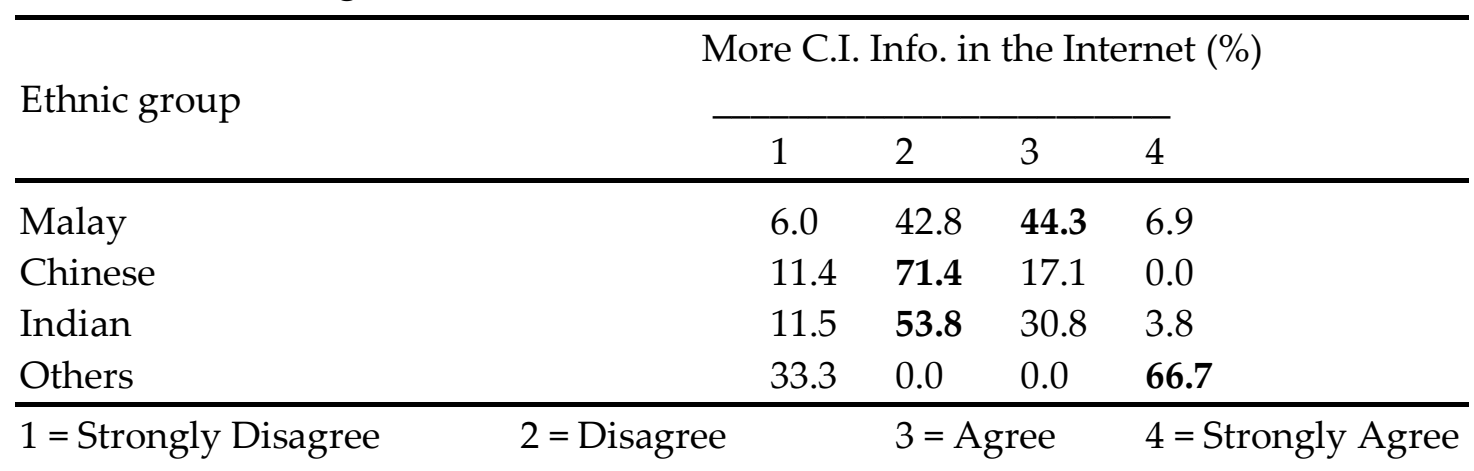




\section{Conclusion}

From the findings it can be concluded that majority of the respondents admitted that they still do not really understand the concept of progressive or Civilizational Islam. The idea is still fuzzy to a great majority of them. Even though they are aware of the concept introduced by the government fifteen years ago, they feel that the information disseminated through the main stream print and electronic media in the country is still insufficient. Therefore, the respondents expressed their needs for more information regarding the new concept or approaches to be circulated through the media especially newspapers and television. At any rate, majority of the respondents agree with the government that Civilizational Islam is just a new approach in developing and bringing modernization to the nation. This view proved that the campaign has achieved certain milestone since it managed to change the respondents' view of the concept. Earlier when it was first introduced, certain quarters even regarded Civilizational Islam as a new religion. The leaders of the government through speeches, media conferences and articles in the conventional media and the internet reiterated that besides its various brand names, Civilizational Islam is just a new approach aimed at developing a civilization. This effort seemed to be fruitful when this study found that respondents' perception towards the concept is now in line with the authorities' intention.

Nevertheless, majority of the respondents still could not differentiate between Inculcation of Islamic Values Policy, Islam Hadhari and Wasatiyah. The Inculcation of Islamic Values Policy was launched by the former premier Tun Dr Mahathir Mohamad during his reign. In his speech delivered in 2000 Tun Dr Mahathir stressed that through the Islamic policy the people of Malaysia had witnessed vast development that benefited them especially the Muslims. Among others he mentioned the International Islamic University of Malaysia, The Bank Islam (Islamic Banking), and The Ar-Rahn (Islamic Pawn System) as examples. Thus the old policy has yielded concrete evident to be seen by the people. Unfortunately the Islam Hadhari and Wasatiyah is still too indistinguishable to them, and far from showing any tangible evidence. Therefore, a majority of them considered the new concept as just a new name of the previous one. Undeniably the media should be used extensively to make the people understand the similarities and the differences between the the concepts. 


\section{Bibliography}

Abdullah Ahmad Badawi. (2006). Islam hadhari: A model approach for development and progress. Kuala Lumpur: MPH Group Publishing Sdn. Bhd.

Chong, Terence (2005). The Construction of the Malaysian Malay Middle Class: The Histories, Intricacies and Futures of the Melayu Baru. Social Identities 11(6):573587. November 2005.

Hock, O. Y. (1991). Multi-racial politics in Malaysia. Kuala Lumpur: Pelanduk Publication (M) Sdn. Bhd.

Ibn Khaldun. (1993). Mukaddimah Ibn Khaldun. Kuala Lumpur: Dewan Bahasa dan Pustaka.

Lee Hock Guan. (2006). Globalization and Ethnic Integration in Malaysian Education. In Saw Swee-Hock \& K. Kesavapany (Eds.), Malaysia: Recent Trends and Challenges (p. 232). Singapore: Utopia Press Pte. Ltd.

Mahathir Mohammad. (2000). Globalization, smart partnership, and government. In Hashim Makaruddin (Ed.). Selected speeches by Dr. Mahathir Mohammad Prime Minister of Malaysia. Kuala Lumpur: Pelanduk Publications (M) Sdn. Bhd.

Mahathir Mohammad. (2000). Islam, knowledge and other affairs. In Hashim Makaruddin (Ed.). Selected speeches by Dr. Mahathir Mohammad Prime Minister of Malaysia. Kuala Lumpur: Pelanduk Publications (M) Sdn. Bhd.

Mahathir Mohammad. (2006). Islam, knowledge, and other affairs. Kuala Lumpur: MPH Group Printing Sdn. Bhd.

Means, Gordon P. (1991). Malaysian Politics: The Second Generation. Oxford: Oxford University Press.

Mohamed Salleh Abas (1987). Sejarah Perlembagaan Malaysia. Kuala Lumpur: Dewan Bahasa dan Pustaka. 